\section{The effects of kaolin, bentonite and zeolite dietary supplemen- tation on broiler chickens meat quality during storage}

\author{
Mohsen Safaei, ${ }^{1}$ Razieh Rezaei, ${ }^{2}$ \\ Fatollah Boldaji,3 Behrooz Dastar, ${ }^{3}$ \\ Mojtaba Taran, 1 Saeed Hassani3 \\ 1Department of Nanobiotechnology, \\ Faculty of Science, Razi University; \\ 2Department of Immunology, Medical \\ School, Kermanshah University of \\ Medical Sciences, Kermanshah; ${ }^{3}$ Faculty \\ of Animal Science, Gorgan University of \\ Agricultural Sciences and Natural \\ Resources, Gorgan, Iran
}

\section{Abstract}

The experiment was conducted to determine the effects of broiler chickens dietary kaolin, bentonite and zeolite supplementations on broiler thigh meat water holding capacity (WHC), lipid oxidation (TBARS), $\mathrm{pH}$, and meat color during frozen storage. A total of 448-dayold sexed broiler cockerels were randomly assigned into 28 experimental units. A cornsoybean meal basal diet with 0,15 and $30 \mathrm{~g} / \mathrm{kg}$ kaolin, bentonite and zeolite as feed additive were added to control and 6 dietary treatments. Chickens were slaughtered and the left thighs kept at $-20^{\circ} \mathrm{C}$ and analyzed after 1 and 150 days of storage. Experimental treatments had no effect on meat WHC, pH and color. Freezing at $-20^{\circ} \mathrm{C}$ for 150 days impaired meat quality and caused chicken rancidity; however, lipid oxidation measured by TBARS value was significantly lower in chickens received diets including $15 \mathrm{~g} / \mathrm{kg}$ bentonite and kaolin comparing to control diet after 150 days of frozen storage $(\mathrm{P}<0.05)$. It was concluded that though adding silicate minerals did not significantly influence WHC, pH and color in experimental treatments, they had influenced lipid oxidation and decreased chicken meat rancidity during frozen storage period.

\section{Introduction}

Poultry meat plays an important role in meeting protein needs of modern communities. It consists of high protein, necessary unsaturated fatty acids, as well as minerals; therefore, the consumption rate dramatically increased comparing to other types of meat. ${ }^{1}$ In recent years, consumers look for meat quality and more focus on features such as color, taste and nutritional facts. ${ }^{2}$

Silicate minerals are natural feed additives are applied in poultry dietary due to special and desirable chemical and physical characteristics. ${ }^{3}$ Enhancing the performance, increasing the yield 4,5 improving the health, $, 7,7$ and utilize as a toxin binder and antioxidant 8,9 are some objectives of using silicate minerals in poultry nutrition. There are also a few studies about using silicate minerals in poultry dietary on the quality of meat indicating reduction in intramuscular fat and abdominal fat.10,11 Lipids oxidation is recognized as one of the main problems in meat industry which ultimately leads to rancidity and losing nutritional values in long term storage. ${ }^{12}$ Poultry meat includes much more unsaturated fatty acids with double bond in domestic animals and is more sensitive to oxidation. 13 Therefore, giving some solutions to maintain and preserve the quality of meat in storage time are of crucial importance. One way to increase meat-keeping time, by investigating effective factors of meat quality and lasting stability, is to decrease fat amounts and lipid oxidation. ${ }^{14}$ There are various ways to avoid initiating meat lipids oxidation or to decrease it. Industrial antioxidants are used in meat and meat production industry to reduce meat oxidation; however, recently, resistance has been increased due to some carcinogen properties of these antioxidants. Now, natural antioxidants and other natural feed additives are being more mentioned. 15

According to characteristics of silicate minerals, the present research, for the first time, studied the effect of kaolin, bentonite and zeolite on meat quality during storage. Therefore, this research was designed to evaluate the effects of kaolin, bentonite and zeolite dietary supplementation on broiler thigh meat water holding capacity, lipid oxidation, $\mathrm{pH}$, and meat color during frozen storage.

\section{Materials and Methods}

\section{Birds and diets}

A total of 448 day-old sexed broiler cockerels were randomly assigned into 28 experimental units (replicates) of sixteen chicks each. A corn-soybean meal basal diet with 0,15 and 30 $\mathrm{g} / \mathrm{kg}$ kaolin, bentonite and zeolite were added to control and 6 dietary treatments as feed additives, respectively. Each diet was randomly fed to 4 experimental units for 42 days. The chicks were permitted to use the feed and water ad libitum throughout the experiment. All diets were formulated to be isonitrogenic and isocaloric during the starter and grower periods according to National Research Council (NRC) ${ }^{16}$ recommendation (Table 1). Chickens were reared in a light, temperature and moisture controlled room up to 42 days of age.
Correspondence: Mohsen Safaei, Department of Nanobiotechnology, Faculty of Science, Razi University, Kermanshah, Iran.

E-mail: mohsen_safaei@yahoo.com

Key words: Silicate minerals, feed additives, frozen storage, broiler, meat quality

Acknowledgements: the authors would thank Dr Reza Mirshekar for his sincere skillful assistance.

Contributions: the authors contributed equally.

Conflict of interests: the authors declare no potential conflict of interests.

Received for publication: 21 August 2015.

Revision received: 5 November 2015.

Accepted for publication: 24 November 2015.

This work is licensed under a Creative Commons Attribution NonCommercial 4.0 License (CC BYNC 4.0).

(C) Copyright M. Safaei et al., 2016

Licensee PAGEPress srl, Italy

Veterinary Science Development 2016; 6:6156 doi:10.4081/vsd.2016.6156

\section{Sample collection and storage}

Three 42 days old broilers of each replicate, following $12 \mathrm{~h}$ fasting, were selected according to pen average body weight. They were individually weighed and slaughtered; further, left thighs eviscerated. Chicken thighs immediately carried to the laboratory under iced $\left(4^{\circ} \mathrm{C}\right)$ condition. The thigh muscles were cut into two parts, first part used to evaluate meat factors on day 1 and the second part stored in plastic bags at $-20^{\circ} \mathrm{C}$ for analysis on day 150 .

\section{Analysis of meat quality}

Water holding capacity (WHC) was determined using method described by Castellini and colleagues ${ }^{17}$ as follows. One $g$ of the meat sample placed on tissue paper in a tube and was centrifuged for 4 minutes at $1500 \mathrm{~g}$. The water remained after centrifugation was measured by drying meat samples at $70^{\circ} \mathrm{C}$ overnight. WHC was calculated as:

WHC $=[($ Weight after centrifugation Weight after drying) / Initial weight] $\times 100$

Lipid oxidation was estimated by measuring thiobarbituric acid reactive substances (TBARS) through using the method described by Grau and coworkers. ${ }^{18}$ TBARS amounts were calculated on days 1 and 150 for thighs meat. The thigh muscle $\mathrm{pH}$ was determined using a digital pH meter (WTW-720 Inolab, Weilheim, Germany) following homogenizing 
$10 \mathrm{~g}$ meat sample in $50 \mathrm{~mL}$ of distilled water for 1 minute.

Color was measured by Lovibond Tintometer Cam-System 500 (Amesbury, UK) through using a D65 illuminant and CIE 10 standard observer. The instrument was calibrated by a white-and-black tile prior to analysis in accordance with International Commission on Illumination. The measures were declared as CIELAB L* (lightness) $a^{*}$ (redness) and $b^{*}$ (yellowness) chromaticity coordinates.

\section{Statistical analysis}

Data were analyzed by analysis of variance in a factorial arrangement $(2 \times 7)$ with two times and seven dietary treatments in a completely randomized design using GLM procedures described by Statistical Analyses System (SAS).19 The significant differences of experimental treatment means were compared using Duncan's multiple range test at $5 \%$ probability level.

\section{Results}

The effects of dietary kaolin, bentonite and zeolite supplementation and storage time on WHC, TBARS and pH of thigh meat are presented in Table 2 . TBARS value showed no significant difference $(\mathrm{P}>0.05)$ between treatments on day 1 ; whereas, on day 150 value of
TBARS was significantly lower in chickens received diets including $15 \mathrm{~g} / \mathrm{kg}$ bentonite and kaolin comparing to control diet $(\mathrm{P}<0.05)$. In dietary treatments containing silicate minerals on days 1 and 150, meat water holding capacity and $\mathrm{pH}$ were better than control; however, the differences were numerically not statistically significant $(\mathrm{P}>0.05)$.

The results in Table 3 show the effects of dietary kaolin, bentonite and zeolite supple-

Table 1. Ingredients and chemical composition of basal diets.

\begin{tabular}{lcc}
\hline Treatment & Starter (0-21 day) & Grower (21-42 day) \\
Feed ingredients & & \\
Corn & 587.3 & 648.1 \\
Soybean meal & 360.3 & 300.9 \\
Soybean oil & 14.3 & 17.5 \\
Dicalcium phosphate & 14.1 & 10.5 \\
Limestone & 12.5 & 13.4 \\
Salt & 4.3 & 3.2 \\
Vitamin premix* & 2.5 & 2.5 \\
Mineral premix & 2.5 & 2.5 \\
DL-Methionine & 1.5 & 0.7 \\
Salinomycine & 0.5 & 0.5 \\
Vitamin E & 0.2 & 0.2 \\
Nutrient composition & & \\
Metabolizable energy, Kcal/kg & 2900 & 3000 \\
Crude protein & 208.5 & 187.5 \\
Ca & 9.1 & 8.4 \\
Available P & 4.1 & 3.3 \\
Na & 1.8 & 1.4 \\
Lys & 11.2 & 9.8 \\
Met + Cys & 8.2 & 6.9 \\
\hline
\end{tabular}

*Each kilogram of vitamin premix contained: vitamin A, 3,500,000 IU; vitamin $\mathrm{D}_{3}, 1,000,000 \mathrm{IU}$; vitamin E, $9000 \mathrm{IU}$; vitamin $\mathrm{K}_{3}, 1000 \mathrm{mg}$; vitamin $\mathrm{B}_{1}$ $900 \mathrm{mg}$; vitamin $\mathrm{B}_{2}, 3,300 \mathrm{mg}$; vitamin $\mathrm{B}_{3}, 5,000 \mathrm{mg}$; vitamin $\mathrm{B}_{5}, 15,000 \mathrm{mg}$; vitamin $\mathrm{B} 6,150 \mathrm{mg}$; vitamin B9, $500 \mathrm{mg}$; vitamin $\mathrm{B}_{12}, 7.5 \mathrm{mg}$; biotin, 500 $\mathrm{mg}$; choline chloride, 250,000 mg. ${ }^{\circ}$ each kilogram of mineral premix contained: Mn, 50,000 mg; Fe, 25,000 mg; Zn, 50,000 mg; Cu, 5,000 mg; I, 500 $\mathrm{mg}, \mathrm{Se}, 100 \mathrm{mg}$.

Table 2. Effects of dietary silicate mineral supplementation on water holding capacity (WHC), thiobarbituric acid reactive substances (TBARS) and $\mathrm{pH}$ of thigh meat.

\begin{tabular}{|c|c|c|c|c|c|c|}
\hline \multirow[t]{2}{*}{ Treatments } & \multicolumn{2}{|c|}{ WHC } & \multicolumn{2}{|c|}{ TBARS } & \multicolumn{2}{|c|}{$\mathrm{pH}$} \\
\hline & Day 1 & Day 150 & Day 1 & Day 150 & Day 1 & Day 150 \\
\hline Control & 62.57 & 57.86 & 0.48 & $1.29 \mathrm{a}$ & 6.19 & 6.12 \\
\hline Kaolin, $15 \mathrm{~g} / \mathrm{kg}$ & 64.02 & 59.15 & 0.43 & $0.89 \mathrm{~b}$ & 6.11 & 6.02 \\
\hline Kaolin, $30 \mathrm{~g} / \mathrm{kg}$ & 64.84 & 60.32 & 0.46 & $1.06 \mathrm{ab}$ & 6.16 & 6.10 \\
\hline Bentonite, $15 \mathrm{~g} / \mathrm{kg}$ & 63.76 & 58.95 & 0.41 & $0.86^{\mathrm{b}}$ & 6.14 & 6.05 \\
\hline Bentonite, $30 \mathrm{~g} / \mathrm{kg}$ & 63.08 & 58.28 & 0.45 & $1.02^{\mathrm{ab}}$ & 6.12 & 6.02 \\
\hline Zeolite, $15 \mathrm{~g} / \mathrm{kg}$ & 63.52 & 58.77 & 0.53 & $0.98^{b}$ & 6.10 & 5.96 \\
\hline Zeolite, $30 \mathrm{~g} / \mathrm{kg}$ & 63.63 & 58.87 & 0.44 & $1.03 \mathrm{ab}$ & 6.11 & 6.00 \\
\hline SEM & 1.46 & 1.60 & 0.05 & 0.09 & 0.06 & 0.07 \\
\hline
\end{tabular}

Means within columns with different superscripts show significant difference $(\mathrm{P}<0.05)$

Table 3. Effects of dietary silicate mineral supplementation on lightness $\left(L^{*}\right)$, Redness $\left(a^{*}\right)$ and Yellowness $\left(b^{*}\right)$ of thigh meat

\begin{tabular}{|c|c|c|c|c|c|c|}
\hline \multirow[t]{2}{*}{ Treatments } & \multicolumn{2}{|c|}{ Hunter L* } & \multicolumn{2}{|c|}{ Hunter a* } & \multicolumn{2}{|c|}{ Hunter b* } \\
\hline & 1 & 150 & 1 & 150 & 1 & 150 \\
\hline Control & 62.49 & 47.37 & 9.55 & 13.30 & 2.74 & 3.15 \\
\hline Kaolin, $15 \mathrm{~g} / \mathrm{kg}$ & 63.64 & 49.61 & 9.36 & 13.15 & 2.80 & 2.90 \\
\hline Kaolin, $30 \mathrm{~g} / \mathrm{kg}$ & 64.71 & 50.41 & 9.11 & 12.38 & 2.78 & 2.95 \\
\hline Bentonite, $15 \mathrm{~g} / \mathrm{kg}$ & 63.07 & 47.38 & 9.65 & 13.90 & 2.53 & 2.75 \\
\hline Bentonite, $30 \mathrm{~g} / \mathrm{kg}$ & 62.79 & 45.88 & 9.57 & 13.33 & 2.18 & 3.25 \\
\hline Zeolite, $15 \mathrm{~g} / \mathrm{kg}$ & 64.61 & 52.51 & 9.35 & 12.30 & 2.05 & 2.00 \\
\hline Zeolite, $30 \mathrm{~g} / \mathrm{kg}$ & 65.08 & 47.42 & 9.09 & 13.60 & 2.23 & 2.50 \\
\hline SEM & 1.18 & 2.08 & 0.30 & 0.61 & 0.47 & 0.78 \\
\hline
\end{tabular}


$\mathbf{A}$

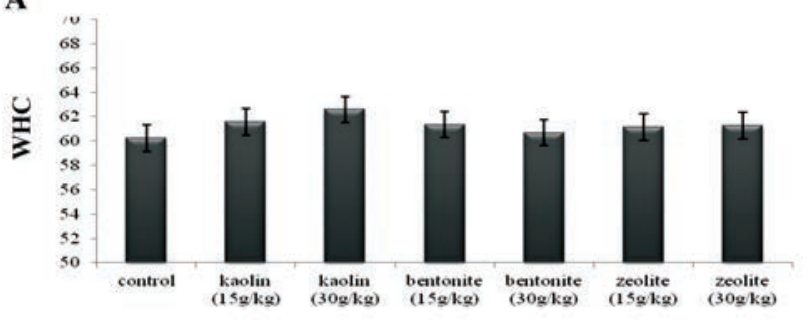

Dietary treatments

B

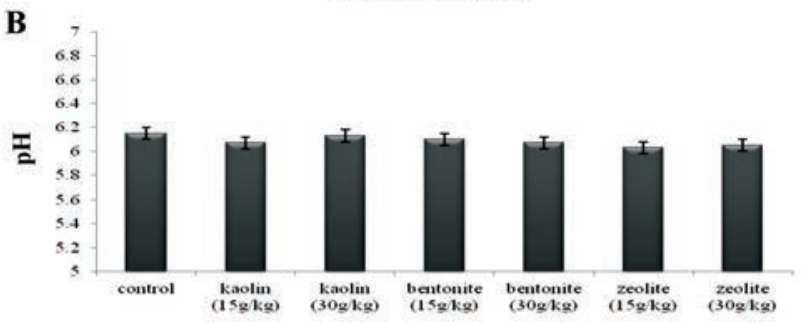

Dietary treatments

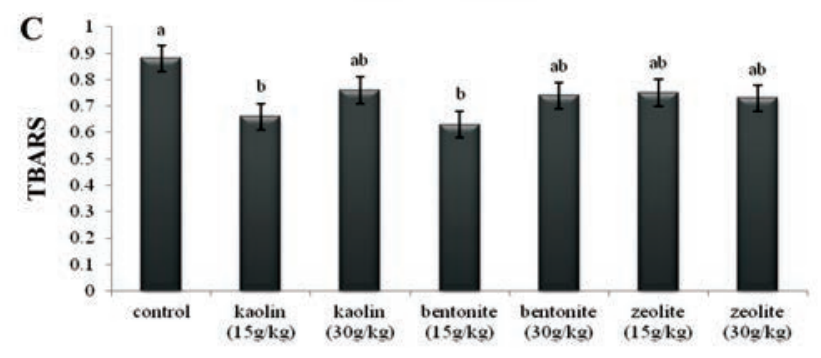

Dietary treatments

Figure 1. A-C) Effect of each dietary treatment on average values of meat quality characteristics for all the periods. The different superscripts show significant difference $(P<0.05)$.
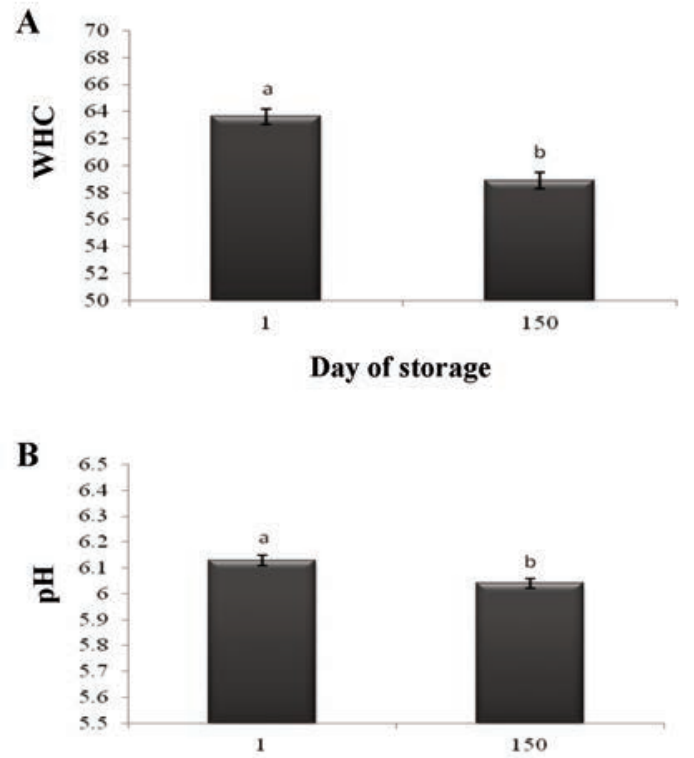

Day of storage

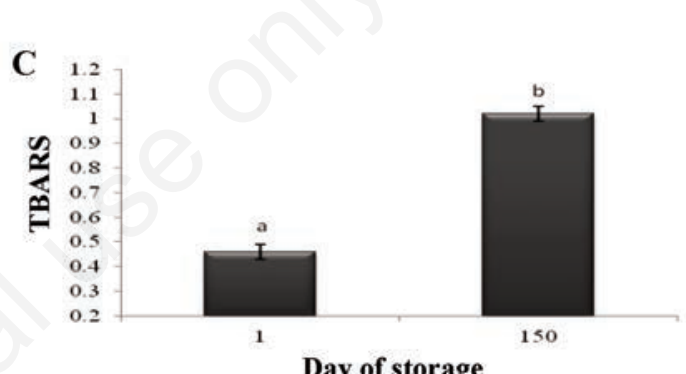

Figure 2. A-C) Effects of all the dietary treatments on average values of meat quality characteristics for each day. The different superscripts show significant difference $(P<0.05)$. mentation and storage time on CIELab thigh meat color. Dietary treatment did not significantly influence on lightness $\left(\mathrm{L}^{*}\right)$, Redness $\left(\mathrm{a}^{*}\right)$ and Yellowness $\left(\mathrm{b}^{*}\right)$ of thigh meat color $(\mathrm{P}>0.05)$. The effect of each dietary treatment on average values of meat quality characteristics for all periods is shown in Figure 1. In dietary treatments containing kaolin, bentonite and zeolite, average values of meat water holding capacity and $\mathrm{pH}$ were better than control, but the differences were not significant $(P>0.05)$. The average value of TBARS was significantly reduced in diets including 15 $\mathrm{g} / \mathrm{kg}$ bentonite and kaolin compared to control diet $(\mathrm{P}<0.05)$. The effects of all dietary treatments on average values of meat quality characteristics for each day are given in Figure 2. The water holding capacity and $\mathrm{pH}$ average values were decreased significantly $(\mathrm{P}<0.05)$ in all dietary treatments since 150 days storage time. The average values of TBARS were significantly higher in all dietary treatments after 150 days frozen storage compared to the first day.

\section{Discussion}

According to results, TBARS was lower in chickens received the diets including $15 \mathrm{~g} / \mathrm{kg}$ bentonite and kaolin compared to control diet after 150 days of storage (Table 2). Meat oxidation developing after slaughter depends on various factors including the amount of meat fat and its fatty acid profile, the levels of meat peroxides and antioxidants, how to process meat (chopped, minced and heated) as well as packaging conditions (light, temperature and duration). ${ }^{20,21}$

The CIELab thigh meat color was not stable during storage time in all dietary treatments (Table 3). Meat color is regarded as an indicator for evaluating meat quality in broilers which myoglobin level, type of muscle, $\mathrm{pH}$, as well as broiler age at slaughter are effective factors on it. ${ }^{22}$

In this experiment, addition of silicate minerals to broiler dietary were effective in improving meat quality characteristics during storage (Figure 1 and 2). It reported that there is a reverse relation between the amount of dietary protein and level of intramuscular fat; further, a direct positive relation seen between dietary energy level and the amount of intramuscular fat indicating that the more intramuscular fat much higher lipid oxidation.22,23 Our previous studies revealed that adding silicate minerals in broiler dietary may lead to a significant increase in the protein digestibility; while, it showed no significant effect on energy digestibility. ${ }^{24}$ Moreover, inclusion silicate minerals to diets may increase meat protein amount and reduce intramuscular fat and abdominal fat in broilers chickens. ${ }^{15}$ Hence, silicate minerals cause reduction of lipid oxidation by improving dietary protein digestibility and reducing the amount of intramuscular fat and abdominal fat.

Huff-Lonergan and Lonergan ${ }^{25}$ have observed that higher meat oxidation leads to decreasing water holding capacity between myofibrils and intensifying water loss. Lipids and proteins oxidations in addition to all fac- 
tors of influencing myofibrils proteins status impact meat drip loss. Previous studies reported that water holding capacity and meat drip loss after slaughter depends on $\mathrm{pH}$ reduction, myofibrils shortening, myosin denature and forming actomyosin. ${ }^{26,27}$ Body metabolic pathways will be stopped after poultry slaughter; however, there still exists some ongoing processes a few minutes after slaughter causing glycogen breakdown in an anaerobic pathway and producing lactic acid. Lactic acid stored in tissues reduces $\mathrm{pH}$ from neutral to acidic. The meat $\mathrm{pH}$ slightly increased, as amino acid deamination and ammonia released a while after slaughtering. ${ }^{26} \mathrm{High} \mathrm{pH}$ causes decreasing shelf life of frozen meat and low $\mathrm{pH}$ causes WHC, as well. ${ }^{28}$

\section{Conclusions}

According to research results, it concluded that adding silicate minerals to broiler chicks dietary may increase oxidative stability and meat keeping time in addition to reducing rancidity over storage time. Therefore, it recommended silicate minerals as an effective feed additive for preserving meat quality of broiler chicks during storage. However, determining their effect mechanism on meat quality requires more studying. Furthermore, studying the effect of simultaneous using of different levels of silicate minerals and natural antioxidants on preserving meat quality during storage is recommended for further future study.

\section{References}

1. Safaei M, Boldaji F, Dastar B, et al. Economic analysis using silicate minerals in broiler chickens diets. ABAH Bioflux 2014;6:216-23.

2. Brunsø K, Fjord TA, Grunert KG. Consumers' food choice and quality perception. The Aarhus School of Business, working paper no.77; 2002. pp 1-60.

3. Shariatmadari F. The application of zeolite in poultry production. Worlds Poult Sci J 2008;64:76-84.

4. Safaei M, Boldaji F, Dastar B, Hassani S. Growth response and tibia bone characteristics in broilers fed diets containing kaolin, bentonite and zeolite. J Anim Feed Sci 2012;21:334-44.
5. Eser H, Yalcin S, Yalcin S, Sehu A. Effects of sepiolite usage in broiler diets on performance, carcass traits and some blood parameters. Kafkas Univ Vet Fak Derg 2012;18:313-8.

6. Safaei M, Jafariahangari Y, Baharlouei A. Effects of dietary inclusion of sodium bentonite on biochemical characteristics of blood serum in broiler chickens. Int J Agr Biol 2010;12:877-80.

7. Safaei M, Jafariahangari Y, Baharlouei A. An evaluation on the effects of dietary kaolin and zeolite on broilers blood parameters, T4, TSH and growth hormones. Pak J Nutr 2011;10:233-7.

8. Magnoli AP, Alonso VA, Cavaglieri LR, et al. Effect of monogastric and ruminant gastrointestinal conditions on in vitro aflatoxin $\mathrm{B} 1$ adsorption ability by a montmorillonite. Food Addit Contam 2013;30:743-9.

9. Wu Y, Wu Q, Zhou Y, et al. Effects of clinoptilolite on growth performance and antioxidant status in broilers. Biol Trace Elem Res 2013;154:1-8.

10. Christaki EV, Florou-Paneri PC, Fortomaris PD, et al. Effects of dietary inclusion of natural zeolite and flaxseed on broiler chickens' body fat deposition in an extended fattening period. Arch Geflugelkd 2006;70:106-11.

11. Safaei M, Boldaji F, Dastar B, et al. Effects of inclusion kaolin, bentonite and zeolite in dietary on chemical composition of broiler chickens meat. Asian J Anim Vet Adv 2013;9:56-63.

12. Kanner J. Oxidative processes in meat and meat products: quality implications. Meat Sci 1994;36:169-89.

13. Morrissey PA, Buckley DJ, Sheehy PJA, Monahan FJ. Vitamin E and meat quality. Proc Nutr Soc 1994;53:289-95.

14. Moloney AP. The fat content of meat and meat products. In: Kerry J, Kerry J, Ledward D, eds. Meat processingImproving quality. Cambridge, UK: Woodhead Publishing Ltd; 2002. pp 137-53.

15. Demeyer D, Honikel K, De Smet S. The world cancer research fund report 2007: a challenge for the meat processing industry. Meat Sci 2008;80:953-9.

16. NRC, National Research Council. Nutrient requirements of poultry. 9th. rev Edn. Washington DC, USA: National Academy Press; 1994.

17. Castellini C, Mugnai C, Dal Bosco A. Effect of organic production system on broiler carcass and meat quality. Meat Sci
2002;60:219-25.

18. Grau A, Guardiola F, Boatella J, et al. Measurement of 2-thiobarbituric acid values in dark chicken meat through derivative spectrophotometry: Influence of various parameters. J Agr Food Chem 2000;48: 1155-9.

19. SAS Institute, SAS/STAT® User's Guide: Statistics, Version 9.1 edition. SAS Institute Inc. Cary, North Carolina; 2003.

20. Min B, Ahn DU. Mechanism of lipid peroxidation in meat and meat products -a review. Food Sci Biotechnol 2005;14:15263.

21. Salakova A, Strakova E, Valkova V, et al. Quality indicators of chicken broiler raw and cooked meat depending on their sex. Acta Vet Brno 2009;78:497-4.

22. Nuernberg K, Kuechenmeister U, Nuernberg G, et al. Effect of storage and grilling on fatty acids in muscle pigs fed plant oils. Eur J Lipid Sci Technol 2006;108:554-60.

23. Mirshekar R, Dastar B, Shabanpour B, Hassani S. Effect of dietary nutrient density and vitamin premix withdrawal on performance and meat quality of broiler chickens. J Sci Food Agr 2013;93:2979-85.

24. Safaei M, Boldaji F, Dastar B, Hassani S. The effect of dietary silicate mineral supplementation on apparent ileal digestibility of energy and protein in broiler chickens. Int J Agr Biol 2012;14:299-302.

25. Huff-Lonergan E, Lonergan SM. Mechanisms of water-holding capacity of meat: the role of postmortem biochemical and structural changes. Meat Sci 2005;71:194-204.

26. Asghar A, Gray JI, Booren AM, et al. Effects of supranutritional dietary vitamin $\mathrm{E}$ levels on subcellular deposition of -tocopherol in the muscle and on pork quality. J Sci Food Agr 1991;57:31-41.

27. Mikulski D, Jankowski J, Zdunczyk Z, et al. The effect of selenium source on performance, carcass traits, oxidative status of the organism, and meat quality of turkeys. J Anim Feed Sci 2009;18:518-30.

28. Aberle ED, Forrest JC, Gerrard DE, et al. Principles of Meat Science, 4th edition. Dubuque, IA: Kendall/Hunt Publishing; 2001. pp 178-211. 